Materiaty I Glosy 



\section{DWA OBLICZA ZASADY PRZEZORNOŚCI W PROCESIE INWESTYCYJNO-BUDOWLANYM}

\section{Wprowadzenie}

W systemie prawa polskiego co najmniej od kilkunastu lat jest obecna zasada przezorności i uznaje się ją za jedną z podstawowych zasad prawa ochrony środowiska. Wynika to z jej zawarcia w Dziale II (Tytuł I. Definicje i zasady ogólne) ustawy z dnia 27 kwietnia 2001 r. Prawo ochrony środowiska ${ }^{1}$ (p.o.ś.), czyli w centralnej ustawie dla polskiego systemu prawa ochrony środowiska ${ }^{2}$. Tę zasadę często rozpatruje się łącznie z zasadą prewencji, jako jej rozwinięcie ${ }^{3}$, która to nakazuje zapobieganie negatywnemu oddziaływaniu na środowisko. Z kolei przezorność wymaga podejmowania środków zapobiegawczych także wtedy, gdy negatywne oddziaływanie może wystąpić tylko potencjalnie. Poniżej skupiono się jednak na wątpliwościach związanych z treścią tej zasady, w szczególności w odniesieniu do procesów inwestycyjno-budowlanych, choć poczyniono także pewne uwagi co do innych aspektów tej zasady.

Zasada przezorności ma swoje źródła w p.o.ś., ale uregulowano ją także w prawie Unii Europejskiej (UE). W związku z tym zasadę tę należy

* Mgr inż., doktorant Uniwersytetu Gdańskiego.

1 Ustawa z dnia 27 kwietnia 2001 r. Prawo ochrony środowiska, tekst jednolity: Dz. U. z 2017 r. poz. 519 z późn. zm.

2 Podobnie J. Ciechanowicz-McLean, Prawo i polityka ochrony środowiska, Warszawa 2009, s. 21.

3 Zob. m.in. P. Korzeniowski, Instytucje prawne ochrony środowiska a proces inwestycyjno-budowlany, Warszawa 2012, s. 37; K. Lew-Gliniecka, Zasada przezorności i zasada prewencji w unijnym prawie ochrony środowiska. Analiza przypadku na tle uwag ogólnych, „Studia Gdańskie. Wizje i Rzeczywistość" 2011, t. 8, s. 207-218. 
rozpatrywać przez pryzmat dwóch, wzajemnie powiązanych, systemów prawnych, choć na gruncie każdego $\mathrm{z}$ nich regulacje te są nieco odmienne. Dlatego właśnie w tytule wskazano, iż zasada ta ma dwa oblicza, zwłaszcza w realizacji procesów inwestycyjno-budowlanych, czyli w toku inwestycji obejmujących wykonywanie robót budowlanych.

Na marginesie rozważań należy odnotować, iż w doktrynie obecne są zdania uznające zasadę przezorności tylko za regułę prawną a nie za zasadę prawa, ponieważ nie wypełnia ona wszystkich istotnych elementów definicji zasady prawa ${ }^{4}$ (brak cechy zasadniczości). Mimo to, nie rozstrzygając o zasadności tych uwag, poniżej zasadę przezorności potraktowano jako zasadę prawa ze względu na jej duże znaczenie w systemie prawa ochrony środowiska.

\section{Zasada przezorności według regulacji polskich}

W prawie polskim zasadę przezorności wyrażono $\mathrm{w}$ art. 6 ust. 2 p.o.ś., wśród zasad ogólnych prawa ochrony środowiska. Zgodnie z tą regulacją zasada przezorności nakazuje podejmować wszelkie (racjonalne) środki zapobiegawcze w odniesieniu do działalności, których skutki nie zostały jeszcze zbadane na tyle, żeby możliwym było uznanie danej działalności za bezpieczną dla środowiska lub ustalenie bezpiecznych norm oddziaływania. Zasada przezorności nie uzasadnia jednak odmowy realizacji niezbadanych dostatecznie przedsięwzięć, a jedynie nakazuje podjąć wszelkie racjonalne środki zapobiegawcze.

Zasada ta nie ma zatem zastosowania w przypadku, kiedy zostały ustalone przez prawodawcę dopuszczalne granice danego rodzaju oddziaływania na środowisko, jak maksymalne dopuszczalne poziomy emisji pól elektromagnetycznych ${ }^{5}$. Wojewódzki Sąd Administracyjny (WSA)

4 Zob. A. Haładyj, Zasady ogólne prawa ochrony środowiska na tle konstytucyjnej zasady zrównoważonego rozwoju, „Prace Naukowe Akademii Ekonomicznej im. Oskara Langego we Wrocławiu" 2007, nr 1190 (Zrównoważony rozwój w teorii ekonomii i w praktyce), s. 141.

5 Rozporządzenie Ministra Środowiska z dnia 30 października 2003 r. w sprawie dopuszczalnych poziomów pól elektromagnetycznych w środowisku oraz sposobów sprawdzania dotrzymania tych poziomów, Dz. U. z 2003 r. Nr 192, poz. 1883. 
w Warszawie w swym wyroku ${ }^{6}$ zwrócił uwagę na konieczność wyeliminowania takich norm emisji, aby organ mógł samodzielnie oceniać oddziaływanie, kierując się zasadą przezorności, co potwierdził też Naczelny Sąd Administracyjny (NSA) ${ }^{7}$. Powyższe wskazuje na pomocniczy charakter tej zasady - ma ona zastosowanie tylko wtedy, kiedy nie można dokonać pełnej oceny sytuacji na podstawie obecnej wiedzy lub wymogów prawa. Co więcej, NSA uznał, że zasada przezorności nie może stanowić samodzielnej podstawy skargi na niezgodność decyzji z prawem, gdyż wymaga uprzedniej konkretyzacji ${ }^{8}$. Bardzo swobodnej wykładni art. 6 ust. 2 p.o.ś. dokonał natomiast WSA w Rzeszowie, który uznał, że zasada przezorności pozwala na przerzucenie ciężaru dowodu na inwestora ${ }^{9}$. $\mathrm{Z}$ takim poglądem trudno się jednak zgodzić i znaleźć dla niego podparcie w treści art. 6 ust. 2 p.o.ś., do czego nawiązano poniżej.

Bardzo dobrze sens zasady przezorności ukazał WSA w Gdańsku ${ }^{10}$, przytaczając za Samorządowym Kolegium Odwoławczym, że zasada przezorności nie upoważnia organów do odmowy zgody na realizację przedsięwzięcia mogącego znacząco oddziaływać na środowisko, a nakazuje dążenie do minimalizacji negatywnego oddziaływania na środowisko, w tym na podstawie wyników oceny oddziaływania przedsięwzięcia na środowisko. Tak rozumiana zasada przezorności wiąże się także z zasadą zrównoważonego rozwoju, wyrażoną w art. 5 Konstytucji Rzeczypospolitej Polskiej ${ }^{11}$ oraz rozwiniętą w art. 3 pkt 50 p.o.ś. Zasada przezorności w rozumieniu p.o.ś. nie sprzeciwia się bowiem dokonywaniu rozwoju społecznego i gospodarczego. Nakazuje jednak zachowanie ostrożności $\mathrm{w}$ dokonywaniu tego rozwoju, polegającej na zapobieganiu niezbadanym oddziaływaniom na środowisko. To z kolei koresponduje $\mathrm{z}$ wywodzonym z zasady zrównoważonego rozwoju obowiązkiem zachowania odpowiedniego stanu środowiska i procesów zachodzących w przyrodzie

6 Wyrok WSA w Warszawie z dnia 30 czerwca 2010 r., IV SA/Wa 2094/09, Centralna Baza Orzeczeń Sądów Administracyjnych (dalej: CBOSA), http:/ / orzeczenia.nsa.gov.pl/.

7 Wyrok NSA z dnia 4 stycznia 2011 r., II OSK 2319/10, CBOSA.

8 Wyrok NSA z dnia 14 czerwca 2017 r., II OSK 1670/16, CBOSA; podobnie wyroki NSA: z dnia 16 marca 2017 r., II OSK 1597/15 oraz z dnia 7 sierpnia 2015 r., II OSK 3033/13, CBOSA.

9 Wyrok WSA w Rzeszowie z dnia 31 maja 2017 r., II SA/Rz 150/17, CBOSA.

10 Wyrok WSA w Gdańsku z dnia 23 lutego 2017 r., II SA/Gd 402/16, CBOSA.

11 Konstytucja Rzeczypospolitej Polskiej z dnia 2 kwietnia 1997 r., Dz. U. z 1997 r. Nr 78, poz. 483 z późn. zm. (dalej: Konstytucja RP). 
dla obecnych i przyszłych pokoleń, przy jednoczesnym umożliwieniu realizacji ich potrzeb.

\section{Zasada przezorności w prawie Unii Europejskiej}

Jak wskazano na wstępie, zasada przezorności jest obecna także w prawie UE, zarówno w aktach prawa pierwotnego, jak i wtórnego. Wynika ona z art. 191 ust. 2 Traktatu z dnia 13 grudnia 2007 r. o funkcjonowaniu Unii Europejskiej ${ }^{12}$ (TFUE), czyli z dawnego art. 174 Traktatu o utworzeniu Wspólnoty Europejskiej, zawartego w Rzymie dnia 25 marca 1957 r. Postawiono tam za cel wysoki poziom ochrony środowiska, oparty "na zasadzie ostrożności oraz na zasadach działania zapobiegawczego [...]”. Taką treść przyjął również art. III-233 Traktatu ustanawiającego Konstytucję dla Europy ${ }^{13}$. Co prawda nazwa „zasada przezorności” nie pada w tych przepisach, to jednak mówi się raczej o zasadzie przezorności aniżeli o zasadzie ostrożności ${ }^{14}$.

Zasada przezorności w prawie UE skupia się na zapobieganiu potencjalnemu negatywnemu oddziaływaniu na środowisko ${ }^{15}$. Służy zatem konserwatorskiej ochronie środowiska, czyli raczej utrzymaniu stanu istniejącego, aniżeli aktywnemu kształtowaniu rozwoju środowiska i przywracaniu jego stanu. Są to działania charakterystyczne dla polityki ochrony środowiska (przyrody) prowadzonej przez UE, zwłaszcza na obszarach Natura $2000^{16}$, chronionych na podstawie dyrektywy ptasiej ${ }^{17}$

12 Traktat z dnia 13 grudnia 2007 r. o funkcjonowaniu Unii Europejskiej (wersja skonsolidowana), Dz. Urz. UE C 202 z 07.06.2016, s. 47.

13 Traktat ustanawiający Konstytucję dla Europy, podpisany 29 października 2004 r. w Rzymie, Dz. Urz. UE C 310 z 16.12.2004.

14 Niektórzy autorzy stosują te określenia naprzemiennie, zob. J. Kielin-Maziarz, Rozporządzenie REACH w świetle zasady ostrożności, "Przegląd Prawa Ochrony Środowiska" 2014, nr 2, s. 161-183.

15 Zob. K. Lew-Gliniecka, Zasada przezorności i zasada prewencji w unijnym prawie ochrony środowiska..., s. 212.

16 Podobnie M. Michalak, Sprawiedliwość ekologiczna a wymóg stosowania zasady przezorności w ramach oceny habitatowej w świetle orzecznictwa Trybunału Sprawiedliwości Unii Europejskiej, [w:] T. Bojar-Fijałkowski (red.), Sprawiedliwość ekologiczna w prawie i praktyce, Gdańsk 2016, s. 203.

17 Dyrektywa Parlamentu Europejskiego i Rady 2009/147/WE z dnia 30 listopada 2009 r. w sprawie ochrony dzikiego ptactwa (wersja ujednolicona), Dz. Urz. UE L20 
i dyrektywy siedliskowej ${ }^{18}$, które zostały zaimplementowane do polskiego systemu prawnego.

Traktaty nie zawierają jednak definicji zasady przezorności. Dlatego też jej treść wyjaśniał Trybunał Sprawiedliwości Unii Europejskiej (TSUE), w szczególności w sprawach inwestycji mogących podlegać ocenie oddziaływania. Przykładem może być wyrok TSUE w sprawie C-127/02 ${ }^{19}$, dotyczącej połowu sercówek na terenie specjalnego obszaru ochrony. TSUE stwierdził, że: „pozwolenie na przedmiotowy plan lub przedsięwzięcie może zostać udzielone pod warunkiem, że właściwe władze krajowe uzyskają pewność, że plan lub przedsięwzięcie nie będzie miało negatywnych skutków na teren" ${ }^{20}$. Zgodnie z dalszą treścią orzeczenia: „Ma to miejsce wówczas, gdy z naukowego punktu widzenia brak jest racjonalnych wątpliwości co do braku wystąpienia takich skutków"21, co określa się stanem „naukowej pewności” ${ }^{22}$. Nieco łagodniejsze wymogi dopuszczono $\mathrm{w}$ sprawie C-236/0123. Powyższe uzupełnia, co do idei słuszny pogląd, że w przypadku braku pewności co do nie występowania negatywnego oddziaływania, zasada przezorności powinna skłaniać do przeprowadzania ocen oddziaływania ${ }^{24}$.

O ile wymogi te mogą być pożądane z punktu widzenia celu ochrony środowiska, to niestety sformułowanie takie jest niebezpieczne dla realizacji inwestycji. Nie uwzględnia bowiem wystarczająco ograniczeń nauki, w tym dostępnych metod i możliwości prowadzenia badań, przez co

z 26.01.2010, s. 7; poprzednia dyrektywa: Dyrektywa Rady 79/409/EWG z dnia 2 kwietnia 1979 r. w sprawie ochrony dzikiego ptactwa, Dz. Urz. UE L103 z 25.04.1979, s. 1.

18 Dyrektywa Rady 92/43/EWG z dnia 21 maja 1992 r. w sprawie ochrony siedlisk przyrodniczych oraz dzikiej fauny i flory, Dz. Urz. UE L206 z 22.07.1992, s. 102.

19 Zob. wyrok TSUE z dnia 7 września 2004 r. w sprawie C-127/02 Landelijke Vereniging tot Behoud van de Waddenzee $i$ Nederlandse Vereniging tot Bescherming van Vogels przeciwko Staatssecretaris van Landbouw, Natuurbeheer en Visserij, pkt 56, 57, 59 i 61, https://curia. europa.eu.

20 Tamże, pkt 56.

21 Tamże, pkt 59 i 61.

22 Zob. wyrok TSUE z dnia 26 października 2006 r. w sprawie C-239/04 Komisja Wspólnot Europejskich przeciwko Republice Portugalskiej, pkt 20, https:/ / curia.europa.eu.

23 Zob. wyrok TSUE z dnia 9 września 2003 r. w sprawie C-236/01 Monsanto Agricoltura Italia SpA i inni przeciwko Presidenza del Consiglio dei Ministri i inni, pkt 106 i 113, https:/ / curia.europa.eu.

24 Zob. wyrok TSUE z dnia 13 grudnia 2007 r. w sprawie C-418/04 Komisja Wspólnot Europejskich przeciwko Irlandii, https:/ / curia.europa.eu. 
uzyskanie nawet „naukowej pewności” może nie być możliwe ${ }^{25}$. Dlatego też $\mathrm{w}$ badaniach naukowych często operuje się prawdopodobieństwem wystąpienia danego zjawiska. Uzyskanie naukowej pewności uniemożliwia też zmienność środowiska oraz ryzyko wywoływania pośredniego wpływu na środowisko przez działalność człowieka. Dlatego tylko w niewielu przypadkach można mówić o braku racjonalnych wątpliwości co do nie wystąpienia negatywnego oddziaływania na środowisko. Uzyskanie pewności jest często niemożliwe - takiej pewności braku wad nie potrafimy uzyskać nawet na taśmie produkcyjnej, w całości zaprojektowanej przez człowieka, gdyż trafiają się braki w toku produkcji.

Pewien kontrast względem takiej przezorności stanowi art. 191 ust. 3 TFUE, wskazujący na uwarunkowania, które należy uwzględnić przy opracowywaniu polityki $\mathrm{w}$ dziedzinie środowiska, a tym samym $\mathrm{w}$ działaniach z zakresu ochrony środowiska. Wśród tych uwarunkowań wymieniono: dostępne dane naukowo-techniczne; warunki środowiska w różnych regionach Unii; potencjalne korzyści i koszty, które mogą wynikać z działania lub zaniechania działania; gospodarczy i społeczny rozwój Unii jako całości i zrównoważony rozwój jej regionów. W ten sposób TFUE w art. 191 ust. 2 i 3 nakazuje nie tylko prowadzenie polityki ochrony środowiska, kierując się zasadą przezorności, ale także z uwzględnieniem stanu wiedzy i środowiska oraz zrównoważonego rozwoju. Na tej podstawie nasuwa się wniosek, że treść zasady przezorności nadawana przez orzecznictwo TSUE jest błędna, jako niezgodna z art. 191 ust. 3 TFUE, dlatego też nie może być stosowana, gdyż prawo wtórne UE musi być zgodne z prawem pierwotnym. Należy przy tym podkreślić, iż poczynione uwagi odnoszą się wyłącznie do sformułowania treści zasady przezorności i nie stanowią oceny orzeczeń w odniesieniu do tych konkretnych spraw.

Warto też zwrócić uwagę na komunikat Komisji Europejskiej w sprawie zasady przezorności ${ }^{26}$, w którym wskazano na możliwość powołania się na zasadę przezorności wyłącznie w uzasadnionych przypadkach. Zasada ta nie ma natomiast służyć unikaniu jakiegokolwiek ryzyka, lecz tylko takiego, które może spowodować istotne negatywne skutki dla śro-

25 Zob. M. Talik, Zasada przezorności a model podejmowania decyzji w obszarze ochrony środowiska, „Prawo i Środowisko” 2005, nr 3, s. 134, 136-137; K.R. Popper, Logika odkrycia naukowego, Warszawa 2002, s. 226.

26 Komunikat Komisji Europejskiej o zasadzie przezorności z dnia 2 lutego 2000 r., Bruksela, COM 2000/1, „Europe Environment”, 8 February 2000, nr 561. 
dowiska, zaś zakaz danej działalności może zostać nałożony wyłącznie wtedy, gdy jest on działaniem proporcjonalnym do zagrożenia dla środowiska tą działalnością.

\section{Jakie oblicze zasady przezorności może być stosowane przed polskimi organami?}

Wydawałoby się, że w Polsce należy stosować zasadę przezorności w treści nadanej przez p.o.ś.. Jednakże w praktyce organy często powołują się na zasadę przezorności zgodną z orzecznictwem TSUE, zwłaszcza w odniesieniu do obszarów Natura 2000 lub ocen oddziaływania. Często aprobują to także sądy administracyjne ${ }^{27}$, wskazując nawet na obowiązek rozstrzygania wszelkich wątpliwości na korzyść obszarów Natura $2000^{28}$. Można spotkać poglądy idące nawet dalej niż orzecznictwo TSUE, zgodnie z którymi „należy wszelkie prawdopodobieństwa wystąpienia negatywnych skutków traktować tak, jak pewność ich wystąpienia" ${ }^{29}$. Zwykle argumentacja opiera się na orzecznictwie TSUE z podkreśleniem wymogu uzyskania pewności, że nie wystąpi negatywne oddziaływanie na środowisko lub przedmiot ochrony.

Przykładem na to, jak daleko sięga powoływanie się przez niektóre polskie organy na orzecznictwo TSUE, może być odmowa przez Regionalnego Dyrektora Ochrony Środowiska w Białymstoku uzgodnienia projektów decyzji o warunkach zabudowy dla terenów w granicach obszaru Natura 2000 Puszcza Białowieska. Sprawa dotyczyła stodoły zaplanowanej na dużej działce, w odległości ok. 200-300 m od zwartej zabudowy wsi w gminie Białowieża ${ }^{30}$. Organ powołał się na zasadę przezorności, opierając się głównie na danych sprzed co najmniej kilku lat oraz okolicznościach, niemal nieudokumentowanych, dotyczących aktywności żubrów i orlika krzykliwego na tym terenie. Organ oparł swoje obawy także na tym, że na zasadzie precedensu inni inwestorzy również będą

27 Zob. m.in. wyroki WSA w Warszawie: z dnia 28 września 2010 r., IV SA/Wa 1402/10 oraz z dnia 9 czerwca 2017 r., IV SA/Wa 627/17, CBOSA.

28 Zob. wyrok WSA w Rzeszowie z dnia 8 czerwca 2017 r., II SA/Rz 203/17, CBOSA.

29 Wyrok WSA w Warszawie z dnia 10 maja 2017 r., IV SA/Wa 2593/16, CBOSA.

30 Postanowienie Regionalnego Dyrektora Ochrony Środowiska w Białymstoku z dnia 7 września 2015 r., sygn. WPN.612.2.354.2015.PS (niepublikowane). 
chcieli zrealizować swoje inwestycje w okolicy. Taką ocenę zaakceptował Generalny Dyrektor Ochrony Środowiska ${ }^{31}$, a nawet WSA w Warszawie ${ }^{32}$. Wypada się jednak zastanowić, jak to jest możliwe, że organowi wciąż nie jest znane oddziaływanie na środowisko stodoły zlokalizowanej na gruntach rolnych, choć podobne obiekty buduje się co najmniej od kilkuset lat. W mojej ocenie zasada przezorności nie ma tutaj zastosowania, gdyż sprawa dotyczyła typowego obiektu na terenie rolnym, czyli przekształconym przez człowieka.

Przedstawiony przypadek niestety nie jest odosobnionym. Podobna sytuacja wystąpiła w odniesieniu do Puszczy Knyszyńskiej ${ }^{33}$. Wówczas NSA zaakceptował odmowę uzgodnienia projektu decyzji o warunkach zabudowy, opartą na zasadzie przezorności. Przyczyną było nie wykazanie przez wnioskodawcę braku negatywnego oddziaływania przedsięwzięcia na przedmiot ochrony obszaru Natura 2000. Podstawą obaw organu była niedaleka lokalizacja dwóch gniazd orlika krzykliwego, a także ryzyko negatywnego oddziaływania na dwa inne gatunki ptaków. Jednocześnie $\mathrm{w}$ bezpośrednim sąsiedztwie już były realizowane podobne inwestycje. Generalny Dyrektor Ochrony Środowiska przyjął wówczas, odmiennie do kazusu z Puszczy Białowieskiej, że każdą sprawę rozpatruje się indywidualnie i sąsiadująca zabudowa nie ma w tym kontekście znaczenia. NSA w uzasadnieniu podzielił stanowisko WSA w Warszawie, że do dopuszczenia realizacji inwestycji na obszarach Natura 2000 konieczne jest wykluczenie znaczącego negatywnego oddziaływania przedsięwzięcia na te obszary, zaś zabudowa sąsiednich działek pozostaje bez znaczenia z punktu widzenia tej sprawy. Należy jednak zauważyć, że taka praktyka organów oraz sądów administracyjnych jest wręcz niebezpieczna dla inwestorów i pewności co do podejmowanych przez nich działań na obszarach Natura 2000. Skutkuje to znacznymi obawami inwestorów lub wykonawców, gdy przychodzi im prowadzić inwestycję w granicach obszaru Natura 2000. Jednocześnie taka odmowa od 1 czerwca 2017 r. byłaby niedopuszczalna na podstawie art. $8 \S 2$ k.p.a. ${ }^{34}$

31 Postanowienie Generalnego Dyrektora Ochrony Środowiska z dnia 31 grudnia 2015 r., sygn. DOA-woll.612.292.2015.ED (niepublikowane).

${ }^{32}$ Wyrok WSA w Warszawie z dnia 16 czerwca 2016 r., IV SA/Wa 721/16, CBOSA.

33 Wyrok NSA z dnia 4 października 2016 r., II OSK 3230/14, CBOSA.

34 Ustawa z dnia 14 czerwca 1960 r. - Kodeks postępowania administracyjnego, tekst jednolity: Dz. U. z 2017 r. poz. 1257. 
W takich sprawach ujawnia się nie tylko konflikt interesu prywatnego z interesem publicznym, ale także konflikt pierwszeństwa między prawem krajowym a prawem UE. Zwolennicy UE wskazują na zasadę pierwszeństwa (prymatu) prawa UE przed prawem krajowym. W mojej ocenie pierwszeństwo stosowania Konstytucji RP przed innymi aktami prawa nie podlega dyskusji, ze względu na treść art. 8 ust. 1 Konstytucji RP, który wskazuje na Konstytucję RP jako najwyższe prawo Rzeczypospolitej. Podobny pogląd wyraził Trybunał Konstytucyjny w wyroku w sprawie K $18 / 04^{35}$.

Na podstawie art. 91 ust. 2 Konstytucji RP prawo pierwotne UE, czyli umowy międzynarodowe (pod warunkiem ratyfikacji), mają pierwszeństwo przed polskimi ustawami, zaraz po Konstytucji RP. Znacznie trudniejszy do ustalenia jest status prawa wtórnego UE. Zwolennicy prawa UE argumentują jego pierwszeństwo na mocy art. 9 Konstytucji RP, zgodnie z którym Polska przestrzega wiążącego ją prawa międzynarodowego. Jest to jednak obowiązek tylko państwa, a nie jego obywateli. Ponadto przestrzeganie prawa międzynarodowego może przyjmować różną formę. Co prawda, w art. 91 ust. 3 Konstytucji RP przyznano pierwszeństwo prawu stanowionemu przez organizację międzynarodową, ale pod warunkiem, że wynika to $\mathrm{z}$ ratyfikowanej umowy międzynarodowej. Z treści art. 2 i 3 TFUE wynika tylko wyłączne uprawnienie organów UE do stanowienia prawa w określonych dziedzinach (wśród nich nie ma ochrony środowiska). Przepisy te jednak nie rozstrzygają o pierwszeństwie obowiązywania lub stosowania norm. Pierwszeństwa nie przewidziano również $\mathrm{w}$ traktacie akcesyjnym ${ }^{36}$ ani $\mathrm{w}$ żadnym $\mathrm{z}$ innych traktatów prawa pierwotnego UE.

35 Wyrok Trybunału Konstytucyjnego z dnia 11 maja 2005 r., K 18/04, Dz. U. z 2005 r. Nr 86, poz. 744; podobnie: postanowienie Trybunału Konstytucyjnego z dnia 10 listopada 2010 r., K 32/09, http:/ / trybunal.gov.pl/.

36 Traktat między Królestwem Belgii, Królestwem Danii, Republiką Federalną Niemiec, Republiką Grecką, Królestwem Hiszpanii, Republiką Francuską, Irlandią, Republiką Włoską, Wielkim Księstwem Luksemburga, Królestwem Niderlandów, Republiką Austrii, Republiką Portugalską, Republiką Finlandii, Królestwem Szwecji, Zjednoczonym Królestwem Wielkiej Brytanii i Irlandii Północnej (Państwami Członkowskimi Unii Europejskiej) a Republiką Czeską, Republiką Estońską, Republiką Cypryjską, Republiką Łotewską, Republiką Litewską, Republiką Węgierską, Republiką Malty, Rzecząpospolitą Polską, Republiką Słowenii, Republiką Słowacką dotyczący przystąpienia Republiki Czeskiej, Republiki Estońskiej, Republiki Cypryjskiej, Republiki Łotewskiej, Republiki Litewskiej, Republiki Węgierskiej, Republiki Malty, Rzeczypospolitej Polskiej, Republiki Słowenii i Re- 
Zasada pierwszeństwa prawa UE przed prawem krajowym wynika tylko z orzecznictwa TSUE ${ }^{37}$, zgodnie z którym państwo nie może dawać pierwszeństwa własnym aktom prawnym przed aktami przyjętymi na zasadzie wzajemności. Orzecznictwo TSUE nie jest jednak umową międzynarodową, w związku z czym pogląd ten nie wpisuje się w dyspozycję art. 91 ust. 3 Konstytucji RP. Warto też zwrócić uwagę na znacznie bardziej rygorystyczny tryb przyjmowania Konstytucji RP niż w przypadku orzekania przez TSUE. Mimo niedopełnienia wymogów zawartych w art. 91 ust. 3 Konstytucji RP, Trybunał Konstytucyjny w wyroku w sprawie K 18/04 dopuścił możliwość nie tylko traktowania prawa UE jako prawa powszechnie obowiązującego w Polsce, ale nawet jego pierwszeństwa przed ustawami. Z poglądem tym jednak trudno się zgodzić, gdyż jest on wprost sprzeczny z obowiązującym prawem, a uzasadnienie wynika jedynie z przyczyn politycznych.

Niezależnie od powyższych kwestii, należy także zauważyć, że powoływanie się przez organy na zasadę przezorności następuje $\mathrm{w}$ postępowaniach administracyjnych, w których obowiązują zasady postępowania administracyjnego. Natomiast zasada przezorności w rozumieniu orzecznictwa TSUE koliduje m.in. z art. 7 i art. $77 \S 1$ k.p.a., zgodnie z którymi organ ma obowiązek dokładnego wyjaśnienia stanu faktycznego i wyczerpującego zebrania materiału dowodowego, podczas gdy zasada przezorności te obowiązki ogranicza. Sprowadza się to do przerzucania ciężaru dowodu na wnioskodawcę, na co zwrócono uwagę także w doktrynie ${ }^{38}$. Niedopełnienie obowiązku zebrania całego materiału dowodowego w sprawie stanowi o wadliwości decyzji administracyjnej ${ }^{39}$. Obowiązku tego, bez wyraźnego przepisu ustawowego, nie wolno prze-

publiki Słowackiej do Unii Europejskiej, podpisany w Atenach w dniu 16 kwietnia 2003 r., Dz. U. z 2004 r. Nr 90, poz. 864.

37 Wyrok TSUE z dnia 15 lipca 1964 r. w sprawie C-6/64 Flaminio Costa przeciwko E.N.E.L., https:/ / curia.europa.eu.

38 Zob. M. Michalak, Sprawiedliwość ekologiczna a wymóg stosowania zasady przezorności w ramach oceny habitatowej w świetle orzecznictwa Trybunatu Sprawiedliwości Unii Europejskiej, [w:] T. Bojar-Fijałkowski (red.), Sprawiedliwość ekologiczna w prawie i praktyce, Gdańsk 2016, s. 203; zob. komentarz do art. 6 p.o.ś. (pkt 50-64), M. Pchałek [w:] M. Górski, M. Pchałek, W. Radecki, J. Jerzmański, M. Bar, S. Urban, J. Jendrośka, Prawo Ochrony Środowiska. Komentarz, Warszawa 2014, s. 115-119.

39 Zob. wyrok NSA we Wrocławiu z dnia 29 września 1997 r., I SA/Wr 700/97, LEX nr 30873; wyrok NSA w Warszawie z dnia 11 czerwca 1981 r., SA 503/81, CBOSA. 
rzucać na stronę $e^{40}$. Mimo to strona nie może być zupełnie bierna i powinna wskazywać fakty lub okoliczności istotne dla sprawy ${ }^{41}$. Należy jednak podkreślić, iż to na organie spoczywa obowiązek pełnego ustalenia stanu faktycznego, nawet $\mathrm{w}$ przypadku nałożenia przez ustawodawcę na stronę obowiązku wykazania pewnych okoliczności ${ }^{42}$ lub dopuszczenia uznania administracyjnego ${ }^{43}$.

Niestety błędnie rozumiana zasada przezorności może pozwalać organom na zaniechanie tych obowiązków, a w przypadku organów ochrony środowiska, nawet do zaniechania obowiązku aktualizacji wyników badań, które są korzystne dla organu. Może to skutkować zastojem w badaniach naukowych zamiast ich wsparcia, które powinno być celem zasady przezorności ${ }^{44}$. Należy przy tym wskazać, że badania takie mogą służyć jako dowód, w myśl art. 75 § 1 k.p.a., ale zgodnie z art. 80 k.p.a. powinny być każdorazowo ocenione tylko pod względem ich treści i aktualności. Organy często, bez względu na aktualność posiadanych wyników, wręcz wymagają od stron, żeby te przedstawiły wyniki badań dające pewność, że nie wystąpi negatywne oddziaływanie planowanego przedsięwzięcia. Taka praktyka narusza art. 75 i art. $76 \S 1$ k.p.a., gdyż organy nadają takim badaniom domniemanie prawdziwości, choć nie są one dokumentami urzędowymi. Ponadto organy nie dołączają zwykle takich opracowań do akt sprawy, przez co utrudniają istotnie stronom możliwość zapoznania się z materiałem dowodowym w sprawie.

Przedstawione wyżej problemy powodują także zagrożenie naruszenia zasady praworządności wyrażonej w art. 7 Konstytucji RP. Zasada ta nakłada na organy obowiązek działania na podstawie i w granicach prawa, czyli nakazuje "opierać się na wyraźnie sformułowanym przepisie prawnym" ${ }^{45}$. Jednakże oparcie odmowy wydania rozstrzygnięcia korzystnego dla wnioskodawcy na niekoniecznie aktualnych wynikach badań przyrodniczych co najmniej budzi wątpliwości co do działania na podstawie i w granicach prawa, zwłaszcza w razie przeciwstawiania tych

40 Zob. wyrok NSA w Warszawie z dnia 7 maja 1985 r., SA 318/85, CBOSA.

${ }_{41}$ Zob. wyrok NSA w Warszawie z dnia 26 października 1984 r., II SA 1205/84, CBOSA; P. Daniel, Administracyjne postępowanie dowodowe, Wrocław 2013, s. 53-61.

42 Zob. wyrok NSA z dnia 20 grudnia 2006 r., II GSK 210/06, CBOSA.

43 Zob. wyrok NSA w Warszawie z dnia 19 lipca 1982 r., II SA 883/82, CBOSA.

44 M. Talik, Zasada przezorności a model podejmowania decyzji w obszarze ochrony środowiska, „Prawo i Środowisko” 2005, nr 3, s. 136.

45 B. Banaszak, Konstytucja Rzeczypospolitej Polskiej. Komentarz, Warszawa 2012, s. 77-78. 
wyników przepisom pozwalającym na zastosowanie tylko wymogów wyraźnie przewidzianych $\mathrm{w}$ przepisach ${ }^{46}$.

Stosowanie zasady przezorności wedle orzecznictwa TSUE - w mojej ocenie - stoi w sprzeczności z art. 191 ust. 3 TFUE i z zasadą zrównoważonego rozwoju wyrażoną $\mathrm{w}$ art. 5 Konstytucji RP, a zatem $\mathrm{z}$ kolejną normą konstytucyjną (obok zasady praworządności). Nic jednak nie stoi na przeszkodzie by stosować $\mathrm{w}$ Polsce zasadę przezorności w treści nadanej przez art. 191 ust. 2 i 3 TFUE. Jest to zgodne z polskim porządkiem prawnym. Jednocześnie tak rozumiana zasada przezorności jest zgodna z zasadą zrównoważonego rozwoju, a także spójna z treścią art. 6 ust. 2 p.o.ś.

\section{Porównanie dwóch oblicz zasady przezorności}

Jak wspomniano, zasada przezorności może mieć w praktyce dwa różne oblicza. Pierwsze z nich, wynikające z p.o.ś. i TFUE, stanowi ochronę środowiska zgodną z zasadą zrównoważonego rozwoju i pozwala na zgodność z zasadą praworządności, a tym samym z Konstytucją RP. Z kolei drugie oblicze omawianej zasady, oparte na orzecznictwie TSUE, stanowi konserwatorską ochronę środowiska, która prowadzi do istotnego ograniczenia części działalności, co nieraz stoi w sprzeczności z powyższymi zasadami konstytucyjnymi. Obydwa oblicza tej zasady służą ochronie środowiska i blokują niekontrolowany rozwój. Jednakże orzecznictwo TSUE ma także istotne skutki negatywne - powoduje często nieuzasadnioną blokadę inwestycji, np. na obszarach Natura 2000.

Oczywiście należy także wziąć pod uwagę fakt, że środowisko jest bardzo złożonym systemem i zależności zachodzące $\mathrm{w}$ nim często nie są do końca zbadane ${ }^{47}$, a oddziaływanie może być także pośrednie lub uwidocznione po pewnym czasie. Jednakże takie znacząco negatywne przypadki są rzadkością. $Z$ tego powodu oblicze prezentowane $\mathrm{w}$ orzecznictwie TSUE jest niebezpieczne $\mathrm{w}$ praktyce, gdyż sięga $\mathrm{w}$ dużej mierze poza źródła prawa, a organy powołujące się na tak rozumianą zasadę przezor-

46 Zob. art. 52 ust. 3 ustawy z dnia 27 marca 2003 r. o planowaniu i zagospodarowaniu przestrzennym, tekst jednolity: Dz. U. z 2017 r. poz. 1073 z późn. zm.

47 Zwraca na to uwagę także Maria Talik, taż, Zasada przezorności a model podejmowania decyzji..., s. 134 . 
ności niekoniecznie opierają się na zweryfikowanych badaniach naukowych (nieraz jedynie na swych obawach). Ma to miejsce także w sprawach prostych inwestycji, przez co uszczerbku doznają zasady postępowania administracyjnego - a w konsekwencji także przestrzeganie praworządności i postrzeganie pewności prawa w Polsce. Niestety praktyka powoływania się przez niektóre polskie organy na zasadę przezorności $\mathrm{w}$ rozumieniu orzecznictwa TSUE, niesie za sobą duże zagrożenie $\mathrm{w}$ postaci blokowania inwestycji z powodu nawet jednej publikacji, choć może być ona oparta na błędnych, niepełnych lub nieaktualnych badaniach.

Między innymi z uwagi na powyższe kwestie WSA w Warszawie stwierdził, że w odniesieniu do typowych inwestycji, takich jak dom jednorodzinny, organy nie mogą powoływać się na zasadę przezorności celem odmowy uzgodnienia projektu decyzji o warunkach zabudowy ${ }^{48}$, nawet na obszarach Natura 2000. Wynika to z faktu, że organ powinien znać oddziaływanie tego rodzaju obiektów i być w stanie wykazać rzeczywistą możliwość wystąpienia negatywnego oddziaływania na środowisko, a nie przerzucać ciężar dowodu na stronę, że takie oddziaływanie nie wystąpi.

Jak zauważył Jerzy Sommer, zasada przezorności była wcześniej znana w prawie niemieckim i tam „zasada przezorności zobowiązuje do zapobiegania wszelkim potencjalnym niebezpieczeństwom środowiskowym poniżej poziomu, od którego można się liczyć z prawdopodobieństwem wystąpienia szkody, a których można uniknąć, wykorzystując osiągnięcia techniki, przy zachowaniu zasady proporcjonalności ${ }^{49}$. Zasada przezorności nie oznacza jednak, że należy unikać wszelkich niebezpieczeństw środowiskowych. Jest to bowiem niemożliwe" ${ }^{50}$. Wydaje się, że właśnie takie rozumienie zasady przezorności powinno być stosowane, gdyż zarówno pozwala na daleko idącą ochronę środowiska (także dla przyszłych pokoleń), jak i nie blokuje możliwości dokonywania rozwoju i realizacji inwestycji. Jednocześnie pozwala na zachowanie zgodności z art. 6 ust. 2 p.o.ś. oraz art. 191 ust. 2 i 3 TFUE. Podobne rozwiązanie przedstawił Marcin Pchałek ${ }^{51}$, wskazując na to, że organ powinien ocenić nie tylko możliwość

48 Zob. Wyrok WSA w Warszawie z dnia 14 marca 2017 r., IV SA/Wa 2702/16, CBOSA.

49 J. Salzwedel, Rechtsgebote der Umweltvorsoge, [w:] F. Niklisch (red.), Prävention im Umweltrecht: Risikovorsorge, Grenzwerte, Haftung, Heidelberg 1988, s. 14.

50 J. Sommer, Podstawy traktatowe wspólnotowego prawa ochrony środowiska, [w:] J. Supernat (red.), Między tradycją a przyszłością w nauce prawa administracyjnego, Wrocław 2009, s. 639.

51 Komentarz do art. 6 p.o.ś. (pkt 61-64), zob. M. Pchałek [w:] M. Górski, M. Pchałek, W. Radecki, J. Jerzmański, M. Bar, S. Urban, J. Jendrośka, Prawo Ochrony Środowiska. Komen- 
wystąpienia negatywnego oddziaływania na środowisko i jego potencjalnych skutków, ale także prawdopodobieństwo jego wystąpienia. Dopiero $\mathrm{w}$ razie prawdopodobieństwa wystąpienia istotnego negatywnego oddziaływania na środowisko wyższego niż niskie, organ powinien być upoważniony do odmowy zgody na realizację przedsięwzięcia. W przeciwnym razie powinny zostać wdrożone wyłącznie środki zapobiegawcze, a w szczególności monitoring oddziaływania na środowisko, aby w razie konieczności możliwa była odpowiednio szybka reakcja na ujawnione zagrożenie.

Warto też zwrócić uwagę na pogląd WSA w Gdańsku², wskazujący na konieczność kierowania się zasadą zrównoważonego rozwoju przy stosowaniu zasady przezorności (zwłaszcza w rozumieniu orzecznictwa TSUE), aby odpowiednio wyważyć interesy prywatne $z$ interesem publicznym. Na kwestię tę zwróciła uwagę również Maria Talik ${ }^{53}$ jako na potrzebę wyważenia pomiędzy koniecznością udowodnienia istotnego negatywnego oddziaływania na środowisko (celem zakazania danej działalności), a koniecznością wykazania braku negatywnego oddziaływania (celem dopuszczenia działalności do realizacji). Jak podkreśla Michał Behnke, należy odróżnić w tej materii „naukowe podstawy dopuszczenia ryzyka [...] w imię zachowania i ochrony środowiska" od „spekulatywnych obaw, odrywających się od adekwatnego związku przyczynowo-skutkowego" ${ }^{54}$. Dopiero wówczas będzie możliwe pełne i zgodne z prawem stosowanie zasady przezorności.

\section{Podsumowanie}

Zasada przezorności w rozumieniu p.o.ś. i TFUE współgra z zasadą zrównoważonego rozwoju - można nawet powiedzieć, że te zasady się

\footnotetext{
tarz, Warszawa 2014, s. 118-119.

52 Wyrok WSA w Gdańsku z dnia 20 czerwca 2017 r., II SA/Gd 428/16, CBOSA.

53 Zob. M. Talik, Zasada przezorności a model podejmowania decyzji..., s. 135; podobnie:
} K. Równy, Obowiązek przezorności zasadą międzynarodowego europejskiego prawa ekologicznego, „Prawo i Środowisko” 1996, nr 4, s. 30.

${ }_{54}$ M. Behnke, Zasada przezorności jako determinanta rozwoju gospodarczego, [w:] M. Nyka, T. Bojar-Fijałkowski (red.), Prawo zarządzania środowiskiem - aspekty sprawiedliwości ekologicznej, Gdańsk 2017, s. 270. 
wzajemnie wspierają. Ponadto Deklaracja z Rio de Janeiro w sprawie Środowiska i Rozwoju ${ }^{55} \mathrm{w}$ zasadzie 15. wskazała na podejście oparte na przezorności. Natomiast zasada przezorności w rozumieniu orzecznictwa TSUE rozwój ten wręcz hamuje. Wielokrotnie zresztą wskazywano już na konieczność rozumienia zasady zrównoważonego rozwoju jako umożliwiającej rozwój z uwzględnieniem wymogów ochrony środowiska, a nie obowiązkowe dostosowanie rozwoju do oczekiwań w sferze ochrony środowiska.

Podsumowując powyższe rozważania, należy zauważyć, że zasada przezorności, choć co do swej idei słuszna, budzi wiele kontrowersji i problemów natury praktycznej. W mojej ocenie nieuzasadnionym jest opieranie się w tym przypadku na orzecznictwie TSUE, którego pozycja $\mathrm{w}$ prawie polskim jest wątpliwa, a przedstawiana argumentacja sprzeczna $\mathrm{z}$ treścią prawa pierwotnego. Zgadzam się natomiast z poglądami, że zasada przezorności jest, a przynajmniej być powinna, ograniczana przez zasadę zrównoważonego rozwoju, która polega na racjonalnym rozwoju gospodarczym, z jednoczesnym poszanowaniem środowiska i odpowiedzialności w tej materii. Dlatego też należy skupiać się na treści nadawanej zasadzie przezorności w p.o.ś. i TFUE, gdyż pozwalają one zarówno na realizację ochrony środowiska, jak i poszanowanie innych zasad prawa oraz dóbr prawnie chronionych. Orzecznictwo TSUE można natomiast potraktować raczej jako pewne postulaty aniżeli ścisłe wymogi prawa. W mojej ocenie uzyskanie jednego, w pełni pozytywnego oblicza zasady przezorności jest obecnie bardzo utrudnione. Wymaga zwiększenia jej skuteczności w niezbędnym zakresie i jednocześnie wyraźnego powiązania zasady przezorności z zasadą zrównoważonego rozwoju, żeby zapewnić ich należyte rozumienie i stosowanie przez organy.

Słowa kluczowe: zasada przezorności, Natura 2000, zasada zrównoważonego rozwoju, proces inwestycyjno-budowlany

55 Deklaracja z Rio do Janeiro w sprawie Środowiska i Rozwoju, [w:] Dokumenty końcowe Konferencji Narodów Zjednoczonych "Środowisko i Rozwój”, Rio de Janeiro 3-4 czerwca 1992 r., Szczyt Ziemi, Warszawa 1993. 


\section{Bibliografia}

\section{Źródła}

\section{Akty prawne}

Konstytucja Rzeczypospolitej Polskiej z dnia 2 kwietnia 1997 r., Dz. U. z 1997 r. Nr 78, poz. 483 z późn. zm.

Traktat z dnia 7 lutego 1992 r. o Unii Europejskiej (wersja skonsolidowana), Dz. Urz. UE C 202 z 07.06.2016, s. 13.

Traktat między Królestwem Belgii, Królestwem Danii, Republiką Federalną Niemiec, Republiką Grecką, Królestwem Hiszpanii, Republiką Francuską, Irlandią, Republiką Włoską, Wielkim Księstwem Luksemburga, Królestwem Niderlandów, Republiką Austrii, Republiką Portugalską, Republiką Finlandii, Królestwem Szwecji, Zjednoczonym Królestwem Wielkiej Brytanii i Irlandii Północnej (Państwami Członkowskimi Unii Europejskiej) a Republiką Czeską, Republiką Estońską, Republiką Cypryjską, Republiką Łotewską, Republiką Litewską, Republiką Węgierską, Republiką Malty, Rzecząpospolitą Polską, Republiką Słowenii, Republiką Słowacką dotyczący przystąpienia Republiki Czeskiej, Republiki Estońskiej, Republiki Cypryjskiej, Republiki Łotewskiej, Republiki Litewskiej, Republiki Wegierskiej, Republiki Malty, Rzeczypospolitej Polskiej, Republiki Słowenii i Republiki Słowackiej do Unii Europejskiej, podpisany w Atenach w dniu 16 kwietnia 2003 r., Dz. U. z 2004 r. Nr 90, poz. 864.

Traktat ustanawiający Konstytucję dla Europy, podpisany 29 października 2004 r. w Rzymie, Dz. Urz. UE C 310 z 16.12.2004.

Traktat z dnia 13 grudnia 2007 r. o funkcjonowaniu Unii Europejskiej (wersja skonsolidowana), Dz. Urz. UE C 202 z 07.06.2016, s. 47.

Ustawa z dnia 14 czerwca 1960 r. - Kodeks postępowania administracyjnego, tekst jednolity: Dz. U. z 2017 r. poz. 1257.

Ustawa z dnia 27 kwietnia 2001 r. Prawo ochrony środowiska, tekst jednolity: Dz. U. z 2017 r. poz. 519 z późn. zm.

Ustawa z dnia 27 marca 2003 r. o planowaniu i zagospodarowaniu przestrzennym, tekst jednolity: Dz. U. z 2017 r. poz. 1073 z późn. zm.

Rozporządzenie Ministra Środowiska z dnia 30 października 2003 r. w sprawie dopuszczalnych poziomów pól elektromagnetycznych w środowisku oraz sposobów sprawdzania dotrzymania tych poziomów, Dz. U. z 2003 r. Nr 192, poz. 1883.

Dyrektywa Rady 79/409/EWG z dnia 2 kwietnia 1979 r. w sprawie ochrony dzikiego ptactwa, Dz. Urz. UE L103 z 25.04.1979, s. 1.

Dyrektywa Rady 92/43/EWG z dnia 21 maja 1992 r. w sprawie ochrony siedlisk przyrodniczych oraz dzikiej fauny i flory, Dz. Urz. UE L206 z 22.07.1992, s. 102-145. 
Dyrektywa Parlamentu Europejskiego i Rady 2009/147/WE z dnia 30 listopada 2009 r. w sprawie ochrony dzikiego ptactwa (wersja ujednolicona), Dz. Urz. UE L20 z 26.01.2010, s. 7-25.

Deklaracja z Rio do Janeiro w sprawie Środowiska i Rozwoju, [w:] Dokumenty końcowe Konferencji Narodów Zjednoczonych "Środowisko i Rozwój", Rio de Janeiro 3-4 czerwca 1992 r., Szczyt Ziemi, Warszawa 1993.

\section{Orzecznictwo}

Wyrok Trybunału Konstytucyjnego z dnia 11 maja 2005 r., K 18/04, Dz. U. z 2005 r. Nr 86, poz. 744.

Postanowienie Trybunału Konstytucyjnego z dnia 10 listopada 2010 r., K 32/09, http://trybunal.gov.pl/.

Wyrok TSUE z dnia 15 lipca 1964 r. w sprawie C-6/64 Flaminio Costa przeciwko E.N.E.L., InfoCuria - Orzecznictwo Trybunału Sprawiedliwości, https://curia.europa.eu.

Wyrok TSUE z dnia 9 września 2003 r. w sprawie C-236/01 Monsanto Agricoltura Italia SpA i inni przeciwko Presidenza del Consiglio dei Ministri i inni, https:// curia.europa.eu.

Wyrok TSUE z dnia 7 września 2004 r. w sprawie C-127/02 Landelijke Vereniging tot Behoud van de Waddenzee $i$ Nederlandse Vereniging tot Bescherming van Vogels przeciwko Staatssecretaris van Landbouw, Natuurbeheer en Visserij, https:/ / curia. europa.eu.

Wyrok TSUE z dnia 13 grudnia 2007 r. w sprawie C-418/04 Komisja Wspólnot Europejskich przeciwko Irlandii, https:/ / curia.europa.eu.

Wyrok TSUE z dnia 26 października 2006 r. w sprawie C-239/04 Komisja Wspólnot Europejskich przeciwko Republice Portugalskiej, https:/ / curia.europa.eu.

Wyrok NSA z dnia 20 grudnia 2006 r., II GSK 210/06, Centralna Baza Orzeczeń

Sądów Administracyjnych (CBOSA), http:/ / orzeczenia.nsa.gov.pl/.

Wyrok NSA z dnia 4 stycznia 2011 r., II OSK 2319/10, CBOSA.

Wyrok NSA z dnia 7 sierpnia 2015 r., II OSK 3033/13, CBOSA.

Wyrok NSA z dnia 4 października 2016 r., II OSK 3230/14, CBOSA.

Wyrok NSA z dnia 16 marca 2017 r., II OSK 1597/15, CBOSA.

Wyrok NSA z dnia 14 czerwca 2017 r., II OSK 1670/16, CBOSA.

Wyrok NSA w Warszawie z dnia 11 czerwca 1981 r., SA 503/81, CBOSA.

Wyrok NSA w Warszawie z dnia 19 lipca 1982 r., II SA 883/82, CBOSA.

Wyrok NSA w Warszawie z dnia 26 października 1984 r., II SA 1205/84, CBOSA.

Wyrok NSA w Warszawie z dnia 7 maja 1985 r., SA 318/85, CBOSA.

Wyrok NSA we Wrocławiu z dnia 29 września 1997 r., I SA/Wr 700/97, LEX nr 38073.

Wyrok WSA w Warszawie z dnia 30 czerwca 2010 r., IV SA/Wa 2094/09, CBOSA. Wyrok WSA w Warszawie z dnia 16 czerwca 2016 r., IV SA/Wa 721/16, CBOSA. 
Wyrok WSA w Gdańsku z dnia 23 lutego 2017 r., II SA/Gd 402/16, CBOSA. Wyrok WSA w Warszawie z dnia 14 marca 2017 r., IV SA/Wa 2702/16, CBOSA. Wyrok WSA w Warszawie z dnia 10 maja 2017 r., IV SA/Wa 2593/16, CBOSA. Wyrok WSA w Rzeszowie z dnia 31 maja 2017 r., II SA/Rz 150/17, CBOSA. Wyrok WSA w Rzeszowie z dnia 8 czerwca 2017 r., II SA/Rz 203/17, CBOSA. Wyrok WSA w Warszawie z dnia 9 czerwca 2017 r., IV SA/Wa 627/17, CBOSA. Postanowienie Regionalnego Dyrektora Ochrony Środowiska w Białymstoku z dnia 7 września 2015 r., sygn. WPN.612.2.354.2015.PS (niepublikowane).

Postanowienie Generalnego Dyrektora Ochrony Środowiska z dnia 31 grudnia 2015 r., sygn. DOA-woll.612.292.2015.ED (niepublikowane).

\section{Literatura}

Banaszak B., Konstytucja Rzeczypospolitej Polskiej. Komentarz, Warszawa 2012.

Behnke M., Zasada przezorności jako determinanta rozwoju gospodarczego, [w:] M. Nyka, T. Bojar-Fijałkowski (red.), Prawo zarządzania środowiskiem - aspekty sprawiedliwości ekologicznej, Gdańsk 2017, s. 265-271.

Ciechanowicz-McLean J., Prawo i polityka ochrony środowiska, Warszawa 2009.

Daniel P., Administracyjne postepowanie dowodowe, Wrocław 2013.

Górski M., M. Pchałek, W. Radecki, J. Jerzmański, M. Bar, S. Urban, J. Jendrośka, Prawo Ochrony Środowiska. Komentarz, Warszawa 2014.

Haładyj A., Zasady ogólne prawa ochrony środowiska na tle konstytucyjnej zasady zrównoważonego rozwoju, „Prace Naukowe Akademii Ekonomicznej im. Oskara Langego we Wrocławiu" 2007, nr 1190 (Zrównoważony rozwój w teorii ekonomii $i$ w praktyce), s. 136-145.

Kielin-Maziarz J., Rozporządzenie REACH w świetle zasady ostrożności, „Przegląd Prawa Ochrony Środowiska" 2014, nr 2, s. 161-183.

Korzeniowski P., Instytucje prawne ochrony środowiska a proces inwestycyjno-budowlany, Warszawa 2012.

Lew-Gliniecka K., Zasada przezorności i zasada prewencji w unijnym prawie ochrony środowiska. Analiza przypadku na tle uwag ogólnych, „Studia Gdańskie. Wizje i Rzeczywistość" 2011, t. 8, s. 207-218.

Michalak M., Sprawiedliwość ekologiczna a wymóg stosowania zasady przezorności w ramach oceny habitatowej w świetle orzecznictwa Trybunału Sprawiedliwości Unii Europejskiej, [w:] T. Bojar-Fijałkowski (red.), Sprawiedliwość ekologiczna w prawie i praktyce, Gdańsk 2016, s. 201-2011.

Popper K.R., Logika odkrycia naukowego, Warszawa 2002.

Równy K., Obowiązek przezorności zasadą międzynarodowego europejskiego prawa ekologicznego, „Prawo i Środowisko” 1996, nr 4.

Salzwedel J., Rechtsgebote der Umweltvorsoge, [w:] F. Niklisch (red.), Prävention im Umweltrecht: Risikovorsorge, Grenzwerte, Haftung, Heidelberg 1988. 
Sommer J., Podstawy traktatowe wspólnotowego prawa ochrony środowiska, [w:] J. Supernat (red.), Między tradycją a przyszłościa w nauce prawa administracyjnego, Wrocław 2009, s. 631-643.

Talik M., Zasada przezorności a model podejmowania decyzji w obszarze ochrony środowiska, "Prawo i Środowisko” 2005, nr 3, s. 132-146.

Komunikat Komisji Europejskiej o zasadzie przezorności z dnia 2 lutego 2000 r., Bruksela, COM 2000/1, „Europe Environment”, 8 February 2000, nr 561.

Stan prawny na dzień 31 października 2017 r.

\section{TWO FACES OF THE PRECAUTIONARY PRINCIPLE IN INVESTING AND BUILDING PROCESS}

\section{Su m mary}

The aim of the article is to analyze the regulations and assumed essence of precautionary principle as a principle in environmental protection law. These considerations are linked to practice during realization of investing and building processes. The precautionary principle is present in polish law and in EU law although there are significant differences between assumed essences of this principle. For these reasons the precautionary principle has two faces. Depending on chosen face of this principle it is a real support for specific environmental protection law requirements and also this principle can cause blocking investing and building processes at given ground. Moreover the basics of regulations and applying of this principle is dubious. Unfortunately current practice of this matter is divergent and doesn't bring good solution of this issue.

Key words: precautionary principle, Natura 2000, principle of sustainable development, investing and building process

\section{ДВЕ СТОРОНЫ ПРИНЦИПА ПРЕДОСТОРОЖНОСТИ В ИНВЕСТИЦИОННО-СТРОИТЕЛЬНОМ ПРОЦЕССЕ}

\section{Резюме}

Целью работы является анализ регулирования и принятого содержанию принципа предосторожности, как принципы права охраны окружающей среды. Размышления отнесены к практике в реализации инвестиционно-строительных процессов. Принцип предосторожности присутствует в польском праве и праве Европейского союза, хотя с существенными от- 
личиями относительно принятого содержания данного принципа. В связи с этим имеет он две разные стороны. В зависимости от выбора стороны данного принципа, содержит он поддержку конкретных требований права охраны окружающей среды, а также может вести к блокаде инвестиционно-строительных процессов на данной территории. Сомнения будят те же основания регулирования и применения данного принципа. К сожалению, нынешняя практика в данном вопросе расходится и не приносит хорошего решения.

Ключевые слова: принцип предосторожности, Природа 2000, принцип уравновешенного развития, инвестиционно-строительный процесс 